\title{
Why Regionalism Has Failed in Latin America: Lack of Stateness as an Important Factor for Failure of Sovereignty Transfer in Integration Projects*
}

Eduardo Pastrana Buelvas**

\section{Introduction}

The advance and retreat of the integration process in Latin America has been a topic of interest and constant debate among scholars and politicians in both Latin America and Europe. The consolidation of organizations of the integration process in the region has planted a permanent question about Latin American states' reluctance to transfer sovereignty to the organizations of such institutions. Even

\footnotetext{
* Article submitted on September 20th, 2013 and approved for publication in November 12th, 2013.

** Eduardo Pastrana Buelvas has a doctorate degree in International Law from University of Leipzig, Germany, and is Lawyer from Universidad Santiago de Cali (USC), Colombia. He is a professor at Pontificia Universidad Javeriana in Bogotá (PUJB), and Director of the Department of International Relations of the Faculty of Political Sciences and International Relations. He heads of the research group of International Relations, Latin America and Integration (GRIALI), and is editor-in-chief of the academic journal Papel Político. E-mail: efpastranab@gmail.com.
}

CONTEXTO INTERNACIONAL Rio de Janeiro, vol. 35, n² 2, julho/dezembro 2013, p. 443-469. 
institutions like the Andean Community of Nations (ACN), whose organization had supranational functions, imitating the institutional development of the European Union, could never put into practice the supra-nationality concept which it theoretically embraced. Therefore, it explains why the ACN has been the object of many interpretations, as well as the failure in Latin America to build integrational spaces where the concept of shared sovereignty can be applied.

There are many causes which could explain this phenomenon. However, in this paper we will, from a comprehensive and interpretative approach, only deal with one of the possible factors that influence the little interest shown by Latin American states to build scenarios of shared sovereignty. In this sense, we consider that national sovereignty, in terms of its classic concept, has not fully developed in Latin America because of the low levels of "stateness" in evidence since the beginning of the Latin American republics. This has limited the development of regional ties necessary to advance to a "deeper" regionalism which would go beyond the current multilateral trade agreements. This phenomenon is also strengthened by the unfinished process of state building in most Latin American countries, which highlights the deficit of complete exercise of internal sovereignty. Therefore, a question arises: how does weak stateness and the unfinished process of its development, impact on those states' reluctance to transfer their sovereignty to regional organizations?

To answer this question, we will begin by contrasting the classical and contemporary ideas of sovereignty to show conceptual elements which will allow us to understand the development of this principle in Latin America and in Europe. Second, we will reflect briefly about the way the concept of sovereignty has been conceived through the Latin American state formation processes, taking as a starting point the Colonial Period and pointing out factors of structural weakness in terms of institutionalism and stateness in the Republican Era. Third, we will interpret the concept of sovereignty in integration thought 
and its three big waves: developmentalism (old regionalism), neo-liberalism (new regionalism), and post hegemonic regionalism. Along these issues a comparative reflection about the meaning of sovereignty in the European Union (EU) formation process and some integration processes in Latin America is undertaken, as well as reflecting on the influence that the theoretical debate has had on both sides of the Atlantic to understand those processes. Fourth, the character of sovereignty in Latin America and its impact on integration will be looked into. Fifth, current regionalism perspectives will be discussed; and, sixth, the relevant relationships in South America will be depicted and the concept of sovereignty and regionalization be analyzed.

\section{The Classic and Contemporary Idea of Sovereignty}

Classical Sovereignty's fundamental object is the territory and the population contained in a country and, furthermore, it constitutes a power, of which the state is the exclusive subject. For authors such as Bodino (1973) and Hobbes (2003), among others, these two conditions of sovereignty, its object and its subject, must be articulated by a series of laws that refer to the sovereign's authority as being a legitimate and unquestionable leader in all cases, even if there may be gaps or spaces of time when the sovereign, whether a prince or a similar figure, will delegate functions to a subject with special characteristics. Thus, classical sovereignty needs a subject with the necessary power and legal justification or force to implement its authority without the response of another power.

Beyond classical sovereignty as an attribute, it is necessary to take into account that sovereignty does not limit one's actions to the domestic dimension of the state, but operates also in an external dimension (HELD, 2002, p. 13). In this case, based on the classic fundamental principles, sovereignty denotes autonomy and independency 
of states against any kind of authority external to it. In the words of Held, "external sovereignty is a quality that political societies possess in relationship to one another; it is associated with the aspiration of a community to determine its own direction and politics without undue interference from other powers" (HINSLEY, 1986 apud HELD, 2002, p. 14).

Indeed, understanding sovereignty as an absolute condition of the state, in XVII century Europe an international scenario came into being in which the relations were between "sovereign states" and absolute authority, but beyond the type of government that ruled these. This "international society" will certainly find in the 1648 Peace of Westphalia its normative assumption, based on the respect of the main object of sovereignty: territory.

This form of classical sovereignty occurred in Europe in the context of a few national geographical segmentations, which are more or less defined, and the formation of governments oriented towards empowering the productive capacity and not merely the extractive capacity of its population, mainly through the contributions of mercantilists and physiocrats (FOUCAULT, 2007, p. 132-134). In contrast, in the case of the European colonies in Latin America, the generation of wealth was fundamentally of extractive character and focused on obtaining "precious materials." This implies, at least, a difficulty for the analysis of sovereignty and stateness in the subcontinent, since its territories in colonial times operated as overseas extensions of European empires.

On the other hand, the dynamic character of international relations presupposes state sovereignty as its main element. According to Malberg (1948, p. 82), it is defined as "Independence on the outer side and superiority on the inside". Therefore, sovereignty refers to the "right of the state to rule over a defined territory" and autonomy is 
the "real power that a nation state has to articulate and pursue their political goals independently" (HELD, 1997, p. 130).

Nowadays, however, states are required to rely on a stronger form of multilateralism in order to solve global problems; because the problems cross boundaries, the most bona fide instrument to approach them is international cooperation. The latter makes it necessary to transfer regulatory powers to supranational institutions, or to establish a network of international regimes, which impose specific duties on the respective realms of states. Hence, international cooperation does not end sovereignty but amplifies and re-substantiates it (BECK, 2004, p. 279). Consequently, the concept of absolute sovereignty is nowadays considered anachronistic because of the great amount of international interactions and interdependence, such that it was defined as a faculty divided in multiple agencies - national and international - and limited by the nature of this plurality (HELD, 1997, p. 169).

\section{Sovereignty, Stateness and Populism in South America}

One must take into consideration the fact that, because these territories were colonies, they were denied the possibility of counting on the presence of the European monarch. Therefore, most of the time ruling was done remotely and without the possibility of the central powers sufficiently exercising the rigorous application of royal mandates in colonized territories. This caused a marginal relationship, but not unimportant, between the European states in formation and their overseas territories. This meant that absolute sovereignty, which was advocated in continental empires, was not strong enough to encompass effectively colonized territories. From this situation another constraint or analytical element arose, which is that the stateness ${ }^{1}$ that advanced in Europe had a rhythm and teleological evolution which was different from what was gestated in the colonies. This dif- 
ference caused fundamentally different outcomes: while Europe advanced in consolidating state institutions capable of handling the complexities arising from the advent of modernity, in the colonies there was no possibility of unlinking religious power and traditional elites from political and economic institutions, not even in the advanced periods of modernity - the late eighteenth and early nineteenth century. In this sense, and as Castro-Gómez correctly observes, referring to the process of building an institutional state in the South American region, "the whole nineteenth century will witness the struggle between the nationalization of property and the "patrimonialization” of state power" (CASTRO-GÓMEZ, 2005, p. 349).

These elements give origin to the identification of a certain initial frailty, which has manifested itself in the two centuries of republican history in Latin America, in that the region, in order to move towards republican governments, developed governments whose most important purpose was the consolidation of new states which arose from the wars of independence. Frequently, the consolidation of external sovereignty from extra-regional threats was, since the beginning of republican history, a main concern. Internal sovereignty was never driven to or by the concept of stateness, namely the conditions for the real exercise of sovereignty; it was an incomplete construction subject to the emergence of internal problems in the new republics.

In Latin America, weak industrialization and political economical limitations, both internal and external, for investing in the defense sector, reduced the possibility of any state being seen as a threat by its neighbors. At the same time, most countries encountered internal conflicts, which strongly pressured the coffers of the republics and limited the management capacities, and accordingly, the development of stateness in both extensive and intensive terms. The main consequence was the inability to exercise sovereignty throughout the territory. While Europe reached more effective stateness and internal sovereignty and the threats to the continent were external to states, however 
close (located in the European space), in Latin America, threats were mainly located outside the sub continental space and internal sovereignty was not consolidated.

Thus, what can be observed from most of the two centuries following Latin American independence is a structural weakness in terms of institutionalism and stateness, which transcended, among other things, the strong influence of the executive function of governing, as a response to that weakness. During the colonial years, a personal relationship with the monarch, who represented authority as a person, was fostered. The new republics demanded loyalty to the state as an abstract entity. Later on, it was difficult for citizens to consider either the state, the nation or the people, as worthy of personal loyalty and as sovereignty bearers. Instead, caudillos, which emerged from civil wars, were the object and source of authority for new societies (KÖNIG, 1998, p. 25). However, these caudillos were the biggest threat which the young republics faced in maintaining their precarious integrations. Only when finally one of these caudillos ${ }^{2}$ was able to impose itself on others, was it possible to consolidate the unification of these new states (ODDONE, 1986, p. 219). These so-called unifying autocracies, which consolidated themselves in the mid nineteenth century, served as obstructions to the centrifuge powers that appeared after the independence wars (GERMANI, 1962, p. 25). Since then, Latin American states have been trying to advance in their state building processes; however, they continue to have more territory than state.

By disregarding the real capacity of state institutions to operate effectively throughout the whole population and territory to which they formally belong, the executive power has served as a cohesion reference for society, which has resulted in strong populism ${ }^{3}$ in most of these countries. In other words, the classic populist model focused on national practices and references, in an introspective and parochial government reality, which attempted to marginalize the international 
system's flows and to respond to internal and external challenges through the construction of suffocating political systems and inwardly focused economic systems, with processes centered on the executive agent. Once market and society are subordinated to the state, autonomous political economic and cultural dynamics are almost non-existent (PASTRANA; VERA, 2011, p. 602).

One of the characteristics of the populist dynamic ${ }^{4}$ is that it frequently privileges internal matters over external ones, which is one of the causes that reinforces the distance between Latin American countries and their lack of interest in building common dynamics and, especially, means of sovereignty transfer. In so far as the distancing has limited the construction of regional ties necessary to the advancement of a "deep" regionalism (the kind that goes beyond the commercial and financial liberal stages) one can ponder whether the non-consolidation of sovereignty in terms similar to those of classical sovereignty, the low levels of stateness developed since the beginning of Latin American republics, and the subordination of the state, society, and market in populist governments, among other factors, play a part that subtracts power and impact from the integration processes in the region. Besides, the unfinished state building process in most Latin American societies, with the subsequent absence of stateness in many parts of the territory, highlights the fact that the full exercise of sovereignty is still in deficit. From this the questions follows: How much does the reluctance of Latin American states to transfer sovereignty in the processes of integration also stem from the fact that they cannot exercise it fully in all their territories? In other words, you can't share what you do not fully possess.

\section{The Concept of Sovereignty in Integration Thinking}

In Latin America, integration thought has developed in three big waves: the first, based on the ECLAC's structural and economic analy- 
Why Regionalism Has Failed in Latin America: Lack of Stateness as an Important Factor...

sis (developmental/developmentalism) which began at the end of the forties and had its peak in the 1960s and 1970s; the second, of neoliberal (neo-liberalism) inspiration and particularly strong in the nineties; and the third, called post-hegemonic (RIGGIROZZI; TUSSIE, 2010 , p. 12$)^{5}$ that developed at the beginning of this century (SERBIN, 2011, p. 50). However, in spite of 60 years of integrationist thinking, or even more if we consider Bolivarianism, a solid integration process has yet to be developed in Latin America.

This thought is closely linked to the fact that integration, analyzed both in its conceptual and historical dimensions, usually uses the process that culminated with the creation of the European Union as a parameter and benchmark. That is why authors like Haas (1967) and others evaluated the Latin American integration as weak, while the European integration is considered strong. Both because of the contemporary political reality of an integrated Europe and the fact that most conceptual developments about integration come from that continent, the comparison is sometimes inevitable. However, this comparison is valid if one accepts the linear character of integration, assuming Latin America is the weak end of integration and Europe as the strong end of the same process, or, in other words, that Latin America is going through - not very effectively - a process that will eventually place it on the same path of integration as the European model. However, more than just comparing two points in an integration continuum, one should highlight that there are two historically produced experiences, which result in two different ways of conceiving both integration and sovereignty.

It is difficult to understand the conceptualization of integration and sovereignty in Europe separate from its historical process. Other than the classic references, which appear in the works of Kant (2002) for example, the integration thinking that gives shape to the analytical axes of federalism-neofederalism on one hand, and functionalism-neofunctionalism on the other, have developed in response to 
the experiences of the World Wars in the first half of the twentieth century. The contemporary developments of federalism come from authors such as Rossi and Spinelli (1941), who based their works on politics more than academia, and who argued in the Ventotene Manifesto ${ }^{6}$ that the survival of nation-states' full sovereignty is a danger to the survival of Europe, since the desire to guarantee one's defense resulted in wars. So they propose supra-nationalism as an alternative solution. This was the idea present when the European order first began to be planned, as, for example, at the 1948 Congress of Europe in The Hague where an economic and political union was discussed in order to prevent European conflicts.

Federalism's classic authors, such as Guy Héraud (1968) and Carl Friedrich (1968), had in mind this historical preoccupation of an inter-European war and argued that the continent could have moved towards a federation which would overcome the traditional mistrust of national sovereignty in favor of a supranational European authority. Despite the efforts of both Paul Schuman's and Jean Monnet with CECA in 1952 to introduce and develop the notion of supranationality, in practice, "inter-gubernamentalism" has been predominant. However, with the Single EU Act (1986) and the EU Treaty (1992), the supra-nationality issue rises again. The result was that neo-federalist authors such as Sidjanski (1992) and José Martín y Pérez de Nanclares (1997) have argued that the process was a result of the European call for federalization.

The preoccupation that propels the development of the functionalism view on integration is not different. David Mitrany (1933), one of the fundamentalists, also had in mind the devastations caused by World War I. He argued that nation-states are not effective in facing challenges that the post-war scenario poses. However, once again, his preoccupation was that this lack of effectiveness could result in a war. He believed that the state was not efficient enough in certain technical functions and that such deficiencies could be alleviated at an interna- 
tional level. He maintained that the solution is not an international state (the idea closest to federalism), but building international entities that can take over some functions of the nation state (Mitrany, 1943, p. 143). His main point was that these institutions would increase interdependence and therefore reduce the risk of war. This focus developed in the 1950's and is linked to the first steps of economic integration of the ECSC.

In a new stage of functionalist theorization, now presented by authors such as Ernst Haas (1958), integration was analyzed in terms of a transfer of loyalty from national institutions to international ones, which would have jurisdiction over national affairs. In the author's opinion, when loyalties don't shift to international authorities, but remain national, integration isn't produced, but maybe political understanding is.

As we can see, both federalism and functionalism start their analysis from the historical event of World War I and the consequences of maintaining European national sovereignties. Both integration propositions answer a problem that is specifically European; thus, it is not surprising that in other parts of the world, i.e. Latin America, significant proposals following this line were not developed. Equally, neo-federalism and neo-functionalism did not propose a universal analysis of integration, but explained the evolution of the European process specifically. However, in Latin America the historical experience did not derive from debates on the dangers of sovereignty and, besides that, did not have a "federalist" experience that could be explained.

In the case of Latin America, the historical trigger that fostered the reflection on integration was not an international war menace, but the preoccupation with underdevelopment, which means that the theme of sovereignty was not thought of in the same terms. In contrast with functionalism and federalism, structuralism served as the analytical 
framework for integration. Since the end of the 1940's, Raúl Prebisch, among others, proposed through the ECLAC to look more closely into Latin American history. The center of his analysis was no longer how to avoid war, or how to build a stable post war order, but how to improve commercial trade conditions between the Northern and Southern hemispheres, or as he would say, between the center and the periphery.

His starting point was that while the center had a modern production apparatus, specialized and diversified, the peripheral zones had an extractive, unspecialized, mono-exporting character. This perspective is inspired by the analysis of authors such as André Gunder Frank (1965), Arghiri Emmanuel (1964) and Samir Amin (1974), who follow the Marxist tradition. There were also Latin American representative authors, such as Prebisch (1986), Furtado (1956), Santos (1966), and Cardoso and Faletto (1977). They all agreed that differences in terms of trade tended to deepen so as to make the conditions of the periphery worse; and so the thinking revolved around how to overcome this difficulty and the way proposed pointed to strengthening the state hand in hand with "closed regionalism".

Thus, while in Europe integration is understood as an alternative to the hazards of strong sovereignty, to the point that Haas (1958) held that integration implied the transfer of sovereignty, in Latin America, sovereignty was not a concern or risk to overcome, and therefore, the idea of ??integration did not lead the way, but structural underdevelopment did. On the contrary, when conceiving that weakness in manufacturing is the cause of the periphery's condition, and that state-centric protectionism is a solution, the purpose of integration was to strengthen Latin American stateness.

After this first wave of Latin American integrationist thought, a second wave closer to "open regionalism" arose in the nineties, consistent with the neoliberal vision that was gaining strength in those years 
in which integration is replaced by openness and harmonization of markets, as a base for inclusion in the international arena based on increasing competitiveness. While the purpose is no longer the strengthening of stateness, it will not lead to the transfer of sovereignty because the goals are primarily commercial, and political integration is not a relevant issue.

\section{The Character of Sovereignty in Latin America and its Impact on Integration}

In the analysis of the relationship between integration and sovereignty in Latin America, the first conclusion is that, neither in the first nor in the second wave of Latin American integration, was the transfer of sovereignty sought, and there were even attempts to strengthen sovereignty. Unlike Europe, where the main threat to Westphalian sovereignty came from the same European states and the resulting solution was to modify the relationships between them, in Latin America the principle of non-intervention has traditionally been respected and external interference has mainly come from players outside the region. Therefore, the relationships to be modified are not those that occur between neighbors, as in the case of Europe, but between Latin American states and extra-regional powers. The result was that what was sought was not a formula to get a group of neighboring states to cease being mutual threats, but how to increase independence from extra-regional powers and make viable the projection of their own autonomy; in other words, to constantly strengthen Westphalian sovereignty reaffirming Calvo and Drago doctrines as opposed to external interference (SERBIN, 2011, p. 59).

As stated, in contrast with Europe, Latin American states have had weak internal sovereignty manifested in an institutional framework incapable of regulating some internal behavior, which has been offset 
by endemic phenomena such as "caudillism" and populism, or at least, by a strong presidential function. The repetition of these forms of government in which the leader extends his authority by weakening other branches of government has strengthened personalism and paternalism (PASTRANA; VERA, 2012, p. 316).

This is relevant because, as argued by Koenig-Archibugi (2004), the willingness to cede sovereignty in favor of integration can be explained as an executive branch behavior in an attempt to increase room for maneuvering against the restrictions imposed by internal factors on its behavior. When national institutions have the capability to influence or restrict the executive branch, they choose to cooperate with other heads of state to create supranational entities that are binding upon the state in such a way as to restrict the ability of these institutions to influence national decision-making. In contrast, when the executive branch is autonomous from domestic institutions, they tend to favor less the transfer of sovereignty because it does not increase the executive's discretion. Instead, intergovernmental approaches prevail, and multiple examples of "personalism" and regional or sub regional leadership aspirations become commonplace.

\section{The Regionalism Perspectives}

The third wave of Latin American thought on integration, here called post-hegemonic, has been built in regards to concepts such as region and regionalism. This kind of regionalization has been defined as post-hegemonic, as it is not guided exclusively by trade integration, but implies a re-politization of regional formulation as a resistance to US hegemony, and it is built over collective identity elements - opposed to neoliberal individualism - which asks for social welfare improvement. If it is tackled as regionalism as a whole, a hybrid model emerges, concerned with growth and economic stability, but also with social justice, more or less free market oriented, and a relatively 
new way of confronting the United States' hegemony (RIGGIROZZI; TUSSIE, 2010, p. 12). Overall, ALBA and UNASUR aim to be the answer to the open regionalism approach and the US hegemony, the first wave being more confrontational, the second being more pragmatic, with the development of cooperative approaches to topics such as education, health, social security and regional security.

However, post-hegemonic regionalism shows different paths to consolidate different regionalisms from the European ones guided by the functionalism and federalism; as well as those of the new regionalism, which tie the regionalization process to the market. Entities such as ALBA and UNASUR innovate about ways to understand social cohesion, regional identity, and specificities of regional governance. However, those regionalization forms coexist with others within the same space, but which answer more to the logic of new regionalism (The Pacific Alliance, consisting of Colombia, Peru, Chile and Mexico). The first takes Latin Americanism elements, with aspects of Bolivarism, which are based on the existence of a common history and culture to project a common and autonomous future, especially from the US. The second approach of regionalism maintains the idea of the Monroe Doctrine, a continental unique space - Panamericanism - led by the US and free of the extra-hemispheric influence.

Again, and as with integration, conceptualization also has strong European influence and emerges in the post-World War II era. Amid political, academic, and social debates about the desirable future for a devastated Europe, federalist and functionalist perspectives, amid their different prescriptions, were betting on a common interpretation: the struggle for the defense of the sovereignty of the nation-state was directly responsible for leading Europe (with its epicenter in the Franco-German rivalry) into a general war (HETTNE; SÖDERBAUM, 2008, p. 63). 
This basic idea challenged head on what observers associated with political realism had considered a virtue and the "engine" of European development policy: civic and military industrial competition, plus mutual deterrence between states, strengthened by alliances and temporary counter- alliances (and other geopolitical factors such as rugged terrain), which had secured, since the collapse of the Habsburg Empire, a balance between powers that facilitated both the expansion of free markets and innovative ideas and political pluralism (KENNEDY, 1997) in a kind of "invisible hand" that resulted in indirect benefit to everyone. In Henry Kissinger (1995) one can trace the notion that the individual pursuit of European states' 'national interest', as opposed to the enforcement of a universal moral or collective goal "harmonious" with integralist pretensions, condensed in the imperialist project continued frustration by calculations of power and recurrence of defending territorial security. However, it is also recognized that the complexity and diplomatic "secrecy" of balance of power induced alliances (Bismarckian style) eventually degenerated into a "zero sum ??game"; a scenario in which neither wanted to give in and the key protagonists sought "total victory", so that sovereignty, power, militarization and mass ideologies operated together to result in the "era of massacres" of the first half of the twentieth century (HOBSBAWM, 1998).

Within a very different cognitive framework, Europe begins to be seen as a historical, political, and cultural heritage: the region, in seeking the way out of the legacies of rivalry between powers and realpolitik, also pushed for economic reconstruction which would not depend indefinitely on U.S. funding (Marshall Plan) and was challenged by the rapid advance of Soviet communism in the East (VOYENNE, 1965). Proposals like Héraud's (1968, p. 77) argued that the epicenter of political organization of the nation should go from the nation to the region, which involves overcoming the ethnic criterion that shaped the modern state and recognizing that cultural 
similarities and common purposes can be constituents of political units, in this case, European.

So, the first or "old" regionalism has, since the fifties, put federalism in debate (European states united by a constitution and federal institutions, legislative coordination between the national and the European and collective identity based on a universality of liberal-democratic values) with functionalism (international / European organizations with narrowly defined skills and operating only in critical areas such as trade, transport, productivity and social policy, and institutional arrangements with supranational technocratic economic criteria rather than political) (VOYENNE, 1965; HETTNE; SÖDERBAUM, 2008, p. 63). The "catalyst factor" and common trigger for bracketing sovereignty and thinking of Europe as a region and its future as a collective good, either as a community or federation of states with sectored integration, tacitly or explicitly, was then the negative interpretation given to one of the causes of the two world wars: the unilateral defense of sovereignty.

However, while in the federalist stance, territoriality remains a central attribute of referencing and governance (local and federal), to Mitrany (1965) and the functionalists, the Westphalian space logic must yield entirely in the areas where governance was more efficient when headed by specialized agencies in their jurisdictions.

But appealing to the sovereignty types distinguished by Krasner (2000), what was at stake in the functionalist view was not so much Westphalian sovereignty, consisting of the exclusion of external forces of authority, international law underpinning the political and legal status of states as subjects of international rights and obligations or of interdependence sovereignty, expressed in the actual ability to control internal and external flows that permeate borders; rather, what mattered was to replace the internal sovereignty or stateness, defined in terms of institutional efficiency, either national or local, to 
regulate phenomena and behavior, wherever states were diagnosed as inefficient or ineffective, for new forms of public institutions, although not combined with the transfer of legitimacy and citizen loyalty to these institutions of decision making.

For Hettne and Söderbaum (2008, p. 63-64), this forced "de-politization" led to the emergence of the previously mentioned Haas (1967) neo-functionalist perspective which incorporated the role of politics (pro-integration role of leaders and the emergence of loyalties transferred to policy networks) and the politically guided introduction of vectors or niches that created high levels of positive interdependence ("spillovers") located primarily in the economic field. They enable the explanation, for a time, of the relationship between the sharing of resources and technologies of the coal and steel industry (in the ECSC) and the political goal of achieving the European Common Market. However, the intensification of bipolar competition at the time had a direct impact on the (national) security dimension, and the resurgence of nationalist leaders like De Gaulle in the sixties who brought back the national interest, the state-centrism and negotiations between leaders in both realistic and liberal intergovernmental prospects (HETTNE; SÖDERBAUM, 2008, p. 64).

\section{South America: Sovereignty and Regionalization}

While in Europe the idea of ??"region" was proposed as an alternative to the national criterion that shaped the modern state, in the hope that this would allow Europe to overcome confrontations (Héraud, 1968, p. 77), in Latin America the approach of a limited space composed of common elements that differentiated between internal and external, the idea of ??an extra-regional threat to sovereignty returned. In fact, the idea of ??space that appears in the ECLAC thinking in mid twentieth century, resumed Bolivarianism approaches and nineteenth-century Latin Americanism that speaks of the unity of Latin 
America as a defensive strategy of a multiethnic and multicultural nation against Anglophone and Francophone threats (ARDAO, 2006 , p. 160). In addition to the diversity of nations and cultures, the ECLAC project also includes the plurality of states.

That is why - while the conception of the European region included from the beginning of the postwar concerns about an integration including the transfer of sovereignty - in Latin America the idea of a region did not challenge state-centric logic as the guiding principle of the region. And then, during the nineties when the purpose of international integration was focused more on trade than on the definition of a space, not only is the thought for the formation of a region minimal, but in the absence of policy with integration objectives in this period, the issue of sovereignty is not brought into discussion.

On this point, a reflection about Haas' neofunctionalism is valid (HAAS, 1967, p. 323-325). When comparing the European and Latin American integration, he argues that the latter is weak because it is based on economic purposes difficult to sustain in the long-term. His argument is that integration is not the product of altruism but of convenience, because stakeholders are committed to it only if it is to their own benefit. Therefore, the first thing that usually comes up is economic integration, as this is where the benefits are more tangible in the short term.

The interesting thing is that in analyzing the Latin American case, one attributes its weakness to the fact that while integration begins on an economic level, in the long term it is ephemeral because from there, integration can only move forward if it is guided by a deeper philosophical or ideological commitment. Otherwise, integration based on economic considerations eventually wears down. While projects such as the ECSC, the Economic Community and EURATOM were essentially sustained by economic considerations, they were in step early on with the political calculation for the pacification and regionalization of Europe. In contrast, both ECLAC integration, which 
was the one analyzed by Haas, and the neoliberal integration of the nineties, were not sustained by long-term political projects.

This only began to change in the late twentieth century when a post liberal integration scheme appeared. The end of the Cold War marked the beginning of a period of transition between bipolarity and multipolarity, in which new countries begin to emerge as significant global players. One of those countries, Brazil, began to reconceptualize the issue of region in Latin America and leads a new division, now in South America. Following the Latin Americanist tradition, South America is a space that excludes the United States and Canada, but now for Latin Americans - it also excludes Mexico and Central America. In the first steps of the redefinition of space, integration starts from the economic promotion through MERCOSUR. Then, and in parallel with the construction of UNASUR, the emergence of these political and philosophical purposes which Haas missed in the ECLAC period, become visible.

Finally both MERCOSUR, created in the nineties, and UNASUR, created in the first decade of XXI century, begin to shape a new region for Brazilian foreign policy strategy. Both organizations, the first with a trade character and the second more political, are the institutional face of the regionalization process. Even though it is possible to recognize them as the spearhead of the third integration wave-the post-hegemonic -, supranationality and shared sovereignty are not part of those organizations' objectives. Again, the reason is strongly related to the lack of discussion about national sovereignties, the low level of stateness consolidation in the member states, as well as the value Brazil gives to the region as a means to project its foreign policy.

\section{Conclusions}

Sovereignty cannot be understood as an attribute of government that is based solely on a regulatory framework. Undoubtedly, a key element for sovereignty to be effectively deployed is that the state has 
institutions at both organizational and legal levels in order to be a legitimate government throughout the territory and population. Looking at the Latin American experience of sovereignty building, a low level of stateness has been an important and influential factor. It has limited the strength of sovereignty in several countries of the region and served as a limiting factor in the consolidation of the regional integration spaces.

In Europe, the theoretical and practical developments of integration occurred in response to the two World Wars, which called into question the system of sovereign nation-states, given their propensity to lead to clashes between neighboring countries. In contrast, national sovereignty in Latin America never posed the threat of large-scale international wars, and therefore integration is not thought of as a process to transfer sovereignty or to diminish conflict, but as sociopolitical alliances between similar countries, which from the creation of economic ties could address underdevelopment.

The concept of region emerged in Europe amid the search for a criterion of political organization that could replace the nation state logic. Meanwhile, in Latin America, "region" was always understood as the way of conceiving the space that allowed it to exclude the United States and Europe, who were the main threats to sovereignty. Thus, "region" has been in Latin America a project to strengthen sovereignty, which since the late twentieth century has been politically subdivided into a new region called South America retaining much of this purpose.

\section{Notes}

1. It is important to make difference beetwen statehood and stateness. "Statehood" is an old notion and its definition can be find in all dictionaries and 


\section{Eduardo Pastrana Buelvas}

encyclopedias. Statehood - "the condition or status of being a political state" or "the status of being a recognized independent nation". "Stateness" focuses on state activity, structures and functions and also defines historical, intellectual and cultural dimensions of this phenomenon. It means the degree to which the instruments of government are differentiated from other organizations, centralized, autonomous, and formally coordinated with each other'. Moreover stateness is defined in four dimensions: "(a) creation of the organization for the mobilization of resources: bureaucracy and tax burden; (b) external consolidation of the territory: army; (c) maintenance of internal order: police and judiciary; and (d) state activism in regulatory activities and in economic and social interventionism" (ZAYTSEV, 2013).

2. For example Juan Manuel Rosas Argentina (1834-1851) and José Antonio Páez (1830-1863) in Venezuela.

3. Populism defined as a political strategy with three characteristics. A personal leader to a heterogeneous mass of followers who feel left out and are available for mobilization; the leader reaches the followers in a direct, quasi-personal manner that bypasses established intermediary organizations, especially parties; if the leader builds a new or revives an old populist party, it remains a personal vehicle with a low level of institutionalization (WEYLAND, 2001, p. 381). Moreover to facilitate comparative analysis of different populist expressions, a synthetic construction of populism can be founded on the following five core properties: 1 . a personal and paternalistic, though not necessarily charismatic, pattern of political leadership; 2. a heterogeneous, multi-class political coalition concentrated in subaltern sectors of society; 3 . a top-down process of political mobilization that either bypasses institutionalized forms of mediator or subordinates them to more direct linkages between the leader and the masses; 4 . an amorphous or eclectic ideology, characterized by a discourse that exalts subaltern sectors or is anti-elitist and/or antiestablishment; 5. an economic project that utilizes widespread redistributive or clientelistic methods to create a material foundation for popular sector support (ROBERTS, 1995, p. 88).

4. For instance Álvaro Uribe (Colombian President 2002-2010) approached and conducted foreign policy in the framework of a populist strategy. Foreign policy is one of most effective of the symbolic policies in providing a stage for the actions of a charismatic leader (PASTRANA; VERA, 2011).

5. Thinking about the latest debates I have decided to adopt the post-hegemonic concept of regionalism instead the post-liberal one.

6. The "Ventotene Manifesto for a Free and United Europe" written by two antifascist militants, is considered today by the European Union as one of its foundational references. See: European Commission, The EU founding fathers. 
Why Regionalism Has Failed in Latin America:

Lack of Stateness as an Important Factor...

Available at: $<\mathrm{http}$ //europa.eu/about-eu/eu-history/founding-fathers/pdf/altiero_spinelli_es.pdf>.

\section{References}

AMIN, S. Capitalismo periférico y comercio internacional. Buenos Aires: Ediciones Periferia, 1974.

ARDAO, A. Panamericanismo y latinoamericanismo. In: ZEA, L. América Latina en sus ideas. Mexico City: Siglo XXI Editores, 2006. p. 157-171.

BECK, U. Poder y contrapoder en la era global. La nueva economía política mundial. Barcelona: Paidos, 2004.

BODINO, J. Los seis libros de la República. Madrid: Aguilar, 1973.

CARDOSO, F. H.; FALETTO, E. Dependencia y desarrollo en América Latína. Buenos Aires: Siglo XXI Editories, 1977.

CASTRO-GÓMEZ, S. La hybris del punto cero. Bogotá: Editorial Pontificia Universidad Javeriana, 2005.

EMMANUEL, A. El intercambio desigual. La Habana: Revue Economica, 1964.

FOUCAULT, M. Seguridad, territorio y población. Buenos Aires: Fondo de Cultura Económica, 2007.

FRIEDRICH, C. J. Trends of Federalism in Theory and Practice. London: Pall Mall Press, 1968.

FURTADO, C. Uma economia dependente. Rio de Janeiro: Ministério da Educação e Cultura - Serviço de Documentação, 1956.

GERMANI, G. Clases populares y democracia representativa en América Latina. Desarrollo Económico, v. 2, n. 2, p. 23-43, 1962.

GUNDER FRANK, A. Capitalismo y subdesarrollo en América Latina. La Habana: Editorial de Ciencias Sociales, 1965. 


\section{Eduardo Pastrana Buelvas}

HAAS, E. The Uniting of Europe. Political, Social and Economical Forces 1950-1957. London: Stevens and Sons, 1958.

The Uniting of Europe and the Uniting of Latin America. Journal of Common Market Studies, v. 5, n. 4, 1967.

HELD, D. La democracia y el orden global, del Estado moderno al gobierno cosmopolita. Madrid: Paidos, 1997.

Derechos de los Estados, derechos de los pueblos: tres modelos de soberanía. Revista Post Data, n. 8, p. 11-62, 2002.

HÉRAUD, G. Les principes du fédéralisme et la fédération européenne. Paris: Presses d'Europe, 1968.

HETTNE, B.; SÖDERBAUM, F. The Future of Regionalism: Old Divides, New Frontiers. In: COOPER, A. F.; HUGHES, C.; LOMBAERDE, P. de. Regionalisation and Global Governance: The Taming of Globalisation? New York: Routledge, 2008. p. 61-79.

HOBBES, T. Leviatan. O la materia forma y poder de una república eclesiastica y civil. Buenos Aires: Editorial Losada, 2003.

HOBSBAWM, E. Historia del siglo XX. Buenos Aires: Crítica, 1998.

KANT, I. Sobre la paz perpetua. Madrid: Tecnos, 2002.

KOENIG-ARCHIBUGI, M. International Governance as New Raison d'État? The Case of the EU Common Foreign and Security Policy. European Journal of International Relations, v. 10, p. 147-188, 2004.

KENNEDY, P. Auge y caída de las grandes potencias. Barcelona: Plaza \& Janés, 1997.

KISSINGER, H. La diplomacia. Mexico City: Fondo de Cultura Económica, 1995.

KÖNIG, H.-J. Los movimientos de independencia hispanoamericanos. In: JANIK, D. La literatura en la formación de los Estados hispanoamericanos. Frankfurt am Main: Vervuert, 1998.

KRASNER, S. La soberanía perdurable. Colombia Internacional, n. 53, p. 25-42, 2000. 
Why Regionalism Has Failed in Latin America:

Lack of Stateness as an Important Factor...

MALBERG, R. C. de. Teoría general del Estado. México D.F.: Fondo de Cultura Económica, 1948.

MARTÍN Y PÉREZ DE NANCLARES, J. El sistema de competencias de la Comunidad Europea. Germen iusinternacionalista versus vocación federal. Madrid: McGraw-Hill, 1997.

MITRANY, D. The progress of International Government. New Haven: Yale University Press, 1933.

A Working Peace System. An Argument for the Functional Development of International Organisation. Chicago: Quadrangle Books, 1943.

. The Prospect of Integration: Federal or Functional? Journal of Common Market Studies, London, v. 4, n. 1, p. 119-149, 1965.

ODDONE, J. Regionalismo y nacionalismo. In: ZEA, L. Regionalismo y nacionalismo. Mexico City: Siglo XXI Editores, 1986.

PASTRANA, E.; VERA, D. La estrategia populista en la política exterior de Álvaro Uribe. Revista Papel Político, v. 16, n. 2, p. 599-635, 2011.

. La estrategia populista en la política exterior: las relaciones colombo-venezolanas en la era Uribe-Chavez. In: MÁRQUEZ, M.; PASTRANA, E.; HOYOS, G. El eterno retorno del populismo en América Latina y el Caribe. Bogotá: Clacso, 2012. p. 307-350.

PREBISCH, R. El desarrollo económico de la América Latina y algunos de sus principales problemas. Desarrollo Economico, v. 26, p. 479-502, 1986.

RIGGIROZZI, P.; TUSSIE, D. The Rise of Post-Hegemonic Regionalism in Latin America. In: ___ The Rise of Post-Hegemonic Regionalism. The Case of Latin America. New York: Springer, 2010. p. 1-16.

ROBERTS, K. Neoliberalism and the Transformation of Populism in Latin America: The Peruvian Case. World Politics, v. 48, n. 1, p. 82-116, 1995.

ROSSI, E.; SPINELLI, A. The Ventotene Manifesto. Ventotene: The Altiero Spinelli Institute for Federalist Studies, 1941.

SANTOS, T. dos. Crisis económica y crisis política. Santiago de Chile: Mimeo CESO, 1966. 
SIDJANSKI, D. EI futuro federalista de Europa. De los orígenes de la Comunidad Europea a la Unión Europea. Barcelona: Ariel, 1992.

SERBIN, A. Regionalismo y soberanía nacional en América Latina: los nuevos desafíos. In: ARAVENA, F. R. América Latina y el Caribe. Multilateralismo vs. soberanía: la construcción de la Comunidad de Estados Latinoamericanos y Caribeños. Buenos Aires: FLACSO, 2011. p. 49-98.

VOYENNE, B. Historia de la idea europea. Barcelona: Labor, 1965.

WEYLAND, Kurt. Clarifying a Contested Concept: Populism in the Study of Latin American Politics. Comparative Politics, v. 34, n. 1, p. 1-22, 2001.

ZAYTSEV, D. Indices of "Stateness" and Governance: Damaging Fallacies and Possibly Optimizing Choices. Paper presented at the International Conference on Public Policy, Grenoble, Jun. 2013. Available at: <http://www.icpublicpolicy.org/.../panel_9_s_1_zaytsev.pdf>. Accessed on: June 14th, 2013.

\section{Abstract}

\section{Why Regionalism Has Failed in Latin America: Lack of Stateness as an Important Factor for Failure of Sovereignty Transfer in Integration Projects}

This paper shows, from an interdisciplinary perspective, the incidence of lack of "stateness" and its construction process in Latin American states, as well as showing the reluctance on the part of Latin American states to transfer sovereignty to regional integrational organizations. First, classical and contemporary ideas of sovereignty are contrasted, in order to understand the development of the sovereignty concept in Latin America and Europe. Second, we interpret how the sovereignty concept has been conceived through Latin American states' formation process. Third, the sovereignty process is adressed within integration thinking and its three big waves: the developmental, neoliberal and post-hegemonic waves. Fourth, the concept of sovereignty in Latin America and its impact on the region are discussed critically. Fifth, current regionalism perspectives are explained. Sixth, the current relationship between sovereignty and regionalization in South America is described. And finally, throughout this paper, we 
Why Regionalism Has Failed in Latin America: Lack of Stateness as an Important Factor...

maintain that it is the weakness of "stateness" in the Latin American states which has had an important influence on their reluctance to transfer national sovereignty to regional integration institutions.

Keywords: Sovereignty - Integration - Stateness - Regionalism 